\title{
THE INFLUENCE OF RAILWAYS ON THE ECONOMY OF THE NORTH EAST OF THE DON COSSACK HOST REGION (60s - 90s OF THE $19^{\text {th }}$ CENTURY)
}

\author{
Andrei V. Lunochkin \\ Volgograd State University, Volgograd, Russian Federation
}

\begin{abstract}
Introduction. The article deals with the issue of the influence of the railways built in the $1860 \mathrm{~s}-$ 1890s in the northeast of the Don Cossack Host Region on the economic development of this region. Methods. Published reports of railway joint-stock companies and archival statistical materials, observations of contemporaries show that this influence was ambiguous. Analysis and results. Gryaz-Tsaritsyn railway, which passed through the densely populated and fertile areas of Khopyorsky and Ust-Medveditsky districts, had the most positive impact on the economy. As a result, grain and livestock production significantly increased, agricultural marketability increased, old major trade and industry centers (Uryupinskaya stanitsa) were developing and new ones (Mikhaylovka sloboda, Privokzalny khutor) appeared. At the same time, the very first Volga-Don railway was mainly transit and had no noticeable impact on the development of the surrounding area, except for Kalach terminal station. TsaritsynTikhoretsk and East-Donetsk railways passed through the sparsely populated and infertile margin of the region, far from large settlements. Their influence on the local economy at first was rather negative and led to the collapse of the traditional horse carriage. The old trade centers, Nizhne-Chirskaya stanitsa and Kalach-on-Don khutor, were put in unfavorable conditions, which led to the slowdown in their development and the outflow of goods and traders to Oblivskaya and Morozovskaya railway stations.

Key words: Don Cossack Host Region, Khoper District, Ust-Medveditsky District, Vtoroy Donskoy District, post-reform period (60s -90 s of the $19^{\text {th }}$ century), economy, railways.

Citation. Lunochkin A.V. The Influence of Railways on the Economy of the North East of the Don Cossack Host Region (60s $-90 \mathrm{~s}$ of the $19^{\text {th }}$ Century). Vestnik Volgogradskogo gosudarstvennogo universiteta. Seriya 4. Istoriya. Regionovedenie. Mezhdunarodnye otnosheniya [Science Journal of Volgograd State University. History. Area Studies. International Relations], 2019, vol. 24, no. 4, pp. 34-44. (in Russian). DOI: https://doi.org/10.15688/ jvolsu4.2019.4.3
\end{abstract}

Дата поступления статьи: 30.03.2019

ББК 63.3(2)53-2 Дата принятия статьи: 28.05.2019

\section{ВЛИЯНИЕ ЖЕЛЕЗНЫХ ДОРОГ НА ЭКОНОМИКУ СЕВЕРО-ВОСТОКА ОБЛАСТИ ВОЙСКА ДОНСКОГО (60-90-е ГГ. XIX в.)}

\author{
Андрей Валентинович Луночкин \\ Волгоградский государственный университет, г. Волгоград, Российская Федерация
}

\begin{abstract}
Аннотация. В статье рассматривается вопрос о влиянии построенных в 1860-1890-е гг. на северо-востоке Области войска Донского железных дорог на экономическое развитие этого региона. Отчеты железнодорожных акционерных обществ, опубликованные и архивные статистические материалы, наблюдения соврем менников показывают, что это влияние было неоднозначным. Наиболее положительное воздействие на экономику оказала Грязе-Царицынская дорога, прошедшая по людным и плодородным местностям Хоперского и Усть-Медведицкого округов. В результате там значительно выросло производство зерна и скота, увеличилась товарность сельского хозяйства, росли старые (станица Урюпинская) и появились новые крупные центры торговли и промышленности (слобода Михайловка, хутор Привокзальный Аннинской станицы). В то же время самая первая Волжско-Донская дорога была в основном транзитной и заметного воздействия на

() развитие окрестной территории, кроме хутора Калач на своей конечной станции, не оказала. Царицын-
\end{abstract}


Тихорецкая и Восточно-Донецкая ветви прошли по малонаселенной и неплодородной окраине региона на удалении от крупных населенных пунктов. Их влияние на местную экономику в первое время стало скорее отрицательным, приведя к краху традиционный фурный промысел. В неблагоприятные условия были поставлены старые центры торговли - станица Нижне-Чирская и хутор Калач-на-Дону, что привело к замедлению их развития и оттоку товаров и торговцев на железнодорожные станции Обливская и Морозовская.

Ключевые слова: Область войска Донского, Хоперский округ, Усть-Медведицкий округ, Второй Донской округ, пореформенный период, экономика, железные дороги.

Цитирование. Луночкин А. В. Влияние железных дорог на экономику северо-востока Области войска Донского (60-90-е гг. ХІХ в.) // Вестник Волгоградского государственного университета. Серия 4, История. Регионоведение. Международные отношения. - 2019. - Т. 24, № 4. - С. 34-44. - DOI: https://doi.org/10.15688/ jvolsu4.2019.4.3

Введение. Создание сети железных дорог оказало сильнейшее воздействие на экономическое развитие России во второй половине XIX века. Лишь после появления дешевых и круглогодичных путей сообщения окончательно сформировался единый национальный рынок, стал расти спрос на продукцию сельского хозяйства. Отсталые в хозяйственном отношении регионы быстро втягивались в товарное производство, что приводило к глубоким изменениям в социальных отношениях. Одним из сословий, чей архаичный уклад жизни подвергся значительной трансформации, стало казачество. Настоящая статья посвящена исследованию влияния железных дорог на экономику и социальное развитие трех северо-восточных округов Земли (с 1870 г. Области) войска Донского, ныне находящихся в составе Волгоградской области - Хоперского, Усть-Медведицкого и Второго Донского. В отличие от южных и западных округов, они дольше сохраняли чисто аграрный характер экономики и патриархальный уклад жизни.

Развитию сельского хозяйства Дона в пореформенный период, крестьянскому и казачьему хозяйству в отечественной историографии традиционно уделяется большое внимание. Этим вопросам были посвящены монография В.Н. Ратушняка [21], коллективная монография ростовских исследователей под редакцией А.М. Анфимова [8], из недавних работ можно отметить труды О.Б. Герман [5] и М.А. Коломейцевой [7]. Проблемы становления донской промышленности, торговли и транспорта изучаются не так интенсивно. По сей день наиболее комплексной работой по экономическому развитию Донской земли во второй половине XIX в. остается монография А.П. Хлыстова [31]. В ней автор кратко рассмотрел исто- рию строительства и эксплуатации Воронежско-Ростовской железной дороги. Однако железные дороги северо-востока Области войска Донского он лишь упомянул. Проблема влияния железных дорог на экономическое развитие этого региона еще не ставилась в научной литературе. Актуальность данной темы подтверждают исследования последних лет, касающиеся соседних регионов [32].

Цель настоящей статьи - закрыть эту лакуну и выяснить, как повлияло проведение Волжско-Донской, Грязе-Царицынской, Царицын-Тихорецкой и Восточно-Донецкой железных дорог на развитие сельского хозяйства, промышленности и торговли Хоперского, Усть-Медведицкого и Второго Донского округов. Это позволит лучше понять общие тенденции и особенности экономического развития различных районов Области войска Донского. Проблемы и противоречия, возникшие в пореформенное время, остро проявились в социальных конфликтах начала XX века.

Методы, материалы. В настоящем исследовании применялись историко-описательный (идиографический), историко-генетический, историко-сравнительный методы, а также количественные методы при изучении статистических источников. Неопубликованные источники по данной теме находятся в фонде Донского областного статистического комитета в Государственном архиве Ростовской области (данные об урожаях, скотоводстве, движении товаров на ярмарках), а также в фонде Департамента железных дорог в Российском государственном историческом архиве (отчеты о движении грузов). Большое количество статистических материалов опубликовано в справочных изданиях конца XIX начала XX века. Списки населенных мест, ма- 


\section{ОТ ВОЛЬНОГО КАЗАЧЕСТВА К СЛУЖИЛОМУ СОСЛОВИЮ}

териалы Донской переписи 1873 г. и Первой всероссийской переписи населения 1897 г. позволяют увидеть динамику роста населенных пунктов, списки фабрично-заводских предприятий - развитие промышленности. В справочниках «Вся Область войска Донского» содержатся перечни торговых предприятий по станицам. Важнейшим источником являются отчеты железнодорожных обществ, позволяющие установить общий объем перевозок, номенклатуру и направления грузопотоков по отдельным станциям. Исключительное значение имеют также историко-статистические описания донских станиц, и особенно Второго Донского округа, производившиеся известным донским исследователем И.В. Тимощенковым, а также материалы периодической печати с корреспонденциями из казачьих станиц и крестьянских слобод.

Анализ. Несмотря на то что возникшие к середине XIX в. промышленные предприятия были сосредоточены на юге и западе Донской земли, первая железная дорога (и не только на Дону, а и на всем Юге России) была построена именно на востоке региона. В марте 1862 г. акционерное общество Волжско-Донской железной дороги и пароходства открыло движение на линии от г. Царицына до хутора Калач Пятиизбянской станицы. Отсюда товары и пассажиры отправлялись вниз по Дону на пароходах, принадлежащих этой же компании. В результате появилась удобная магистраль от Нижней Волги к Азовскому морю. Из пяти станций Волжско-Донской дороги три - Карповская, Кривомузгинская и конечная Донская находились на территории Земли войска Донского.

Волжско-Донская железная дорога (в современной литературе чаще используется название Волго-Донская) сразу привлекла большое количество грузов. За первый календарный год эксплуатации (1863 г.), по данным Департамента железных дорог, по ней было перевезено 16266 пассажиров и 3858429 пудов грузов [15]. В дальнейшем это количество нарастало, и пиковым стал 1869 г., когда железная дорога перевезла 12354223 пудов грузов [16, прил. Х]. В 1870-1880-х гг. объем перевозок по Волжско-Донской дороге стабилизировался в пределах 9-10 млн пудов.

Проведение железной дороги благотворно повлияло на развитие Калача, рядом с ко- торым разместилась конечная станция Донская и речные пристани. Уже 28 января 1863 г. хутор Калач был преобразован в торговое поселение под административным управлением пристава Калачевской пристани. Под будущую застройку поселению было отмежевано 1500 десятин земли [13, с. 96-98]. Хутор быстро превратился в крупный населенный пункт, жители которого почти не занимались сельским хозяйством. Так, если в 1859 г. в хуторе проживало 469 жителей [22, с. 41], то в 1873 г. их насчитывалось уже 1 173, причем здесь имелось всего 6 плугов, 99 лошадей и 150 голов крупного рогатого скота - цифра для Среднего Дона совершенно ничтожная [24, с. 93]. Однако вырасти в полноценный город Калачу не удалось. На западе Области войска Донского в 1872 г. открылась Воронежско-Ростовская железная дорога, и для грузов из центра страны появился более короткий и дешевый путь на Северный Кавказ, нежели долгий и сопряженный с несколькими перевалками маршрут по Волге и Дону. В результате грузооборот Волжско-Донской дороги практически перестал расти - в 1877 г. он составил 8746594 пудов [16, прил. VIII]. В 1878 г. Волжско-Донская дорога была слита с Грязе-Царицынской, а Калач был лишен статуса торгового поселения и снова стал хутором Пятиизбянской станицы.

Тем не менее экономическое развитие хутора продолжалось. В 1878 г. отставной поручик И.В. Петров основал в Калаче-на-Дону механический, чугунолитейный и судостроительный завод, единственный на все соседние округа. В 1903 г. там трудилось 168 рабочих, было произведено продукции на 94400 руб. [26, c. 261]. Завод этот обслуживал потребности железной дороги и донского судоходства. Калач уверенно превращался в экономический центр для всего Среднего Дона. В 1900 г. здесь работало 40 торговых предприятий, что было вполне сопоставимо с крупнейшими станицами Дона. Пять купцов занимались оптово-розничной торговлей хлебом, четверо мукой (и это были единственные мучные торговцы во всем 2-м Донском округе), трое лесом. Об уровне благосостояния жителей хутора можно судить по тому, что в Калаче располагалось 4 посудные лавки из 5 во всем округе [4, с. 445-697]. 
Однако, кроме Калача, Волжско-Донская железная дорога оказала в целом небольшое влияние на прилегающую местность. Даже спустя четверть века после ее открытия С.Ф. Номикосов отмечал: «Большие пристани Качалинская и Калачевская не имеют местного груза; здесь грузится лишь кладь с Волги, подвозимая к Качалину с Дубовки, а к Калачу из Царицына» [12, с. 110]. С Волги на Дон везли в первую очередь лес и лесной товар, железо и железные изделия для Приазовья и Кубани, зерновые на экспорт через Таганрог. С Дона на Волгу шел донецкий антрацит, бакалейные и прочие товары преимущественно импортного происхождения - сахар, вино, табак и т. д. Промежуточные станции ВолжскоДонской дороги, расположенные в бедной засушливой местности, не давали на нее почти никаких грузов. Так, в 1877 г. при общем объеме отправки в 8746594 пуда станция Кривомузгинская отгрузила 743 пуда, а Карповская всего 18 пудов [16, прил. VII]. Такое положение сохранялось и позже. Единственным товаром, который давала на железную дорогу ст. Карповская, стала небольшая часть скота с местной довольно крупной скотной ярмарки. Так, в 1887 г. здесь было погружено скота весом на 1156 пудов [19, с. 20]. Однако большая часть купленного на ярмарке скота отправлялась, как и раньше, своим ходом.

Не смогла Волжско-Донская железная дорога окончательно победить и традиционное направление гужевых перевозок - существующую с середины XVIII в. оживленную дорогу от посада Дубовки на Волге до станицы Качалинской на Дону. На железную дорогу перешла значительная часть грузов оттуда, но далеко не вся. Так, в 1873 г. из Калача было отправлено вниз по Дону 3081385 пудов грузов на 398 судах и 2991234 пуда на пароходных баржах, а также 441 плот леса, a из Качалинской - 416226 пудов грузов на 79 судах и 231 плот леса [10]. Извозный промысел на этом направлении продолжал сохранять свое значение, давая очень хороший заработок населению прилегающей местности. В 1873 г. здесь работало 2000 фур из Качалинской, 600 - из Трехостровянской, 890 Иловлинской, 200 - Новогригорьевской, 50 Старогригорьевской, 50 - Сиротинской станиц, 200 фур из крестьянских слобод Котлубани,
Карповки и Мариновки, а также 1393 фуры иногородних хозяев. На одного хозяина, ходившего обычно с тремя парами волов, заработок за сезон доходил до 100 рублей. Особенной конкуренции со стороны железной дороги, по словам местных жителей, «пока не чувствовалось» [11].

Гораздо большие последствия для экономического развития восточных районов Области войска Донского имела постройка ГрязеЦарицынской железной дороги, прошедшей по восточной окраине Области войска Донского в 1871 году. Акционерное общество Грязе-Царицынской железной дороги открыло движение от Борисоглебска до Царицына в июле 1871 г., а в декабре этого же года поезда пошли и по боковой ветви до станицы Урюпинской. Теперь восток Дона оказался связан с общерусской сетью железных дорог. Здесь открылись станции Алексиково, Урюпино, Ярыженская, Филоново, Панфилово, Кумылга, Себряково, Раковка, Михайло-Чертково (вскоре переименована в Арчеду), Липки, Лог, Иловля, Качалино, Котлубань. Три из них - Филоново, Себряково и Арчеда - располагали паровозными депо и ремонтными мастерскими.

Наиболее значительные обороты после Царицына имела тупиковая станция Урюпино, построенная специально для обслуживания знаменитой на весь Юг России ярмарки. Ярмарочная торговля в 1870-е гг. переживала свой апогей. В Урюпинской станице работало четыре ярмарки - Покровская, Крещенская, Евдокиевская и Вознесенская. По отчету станичного атамана, в 1875 г. на них было привезено товаров на 10175319 руб., а продано на 8378698 рублей. На первые две ярмарки съезжались торговцы со всей России, Покровскую посещали не менее 500 тыс. чел., Крещенскую - 100 тысяч. В структуре ярмарочной торговли все больший удельный вес занимал хлеб и скот. Во время Покровской ярмарки закупалось до 50 тыс. четвертей хлеба и около 30 тыс. голов крупного рогатого скота, столько же овец [30, с. 13-14].

Проведение железной дороги резко стимулировало в первую очередь хлебную торговлю. По наблюдениям И. Тимощенкова, до 1870 г. спрос на хлеб был небольшой, после же начался настоящий хлебный бум, цены на зерно существенно поднялись. Хлеб 


\section{ОТ ВОЛЬНОГО КАЗАЧЕСТВА К СЛУЖИЛОМУ СОСЛОВИЮ}

закупался не только на ярмарке. Крупнейшими скупщиками в Хоперском округе были купцы Иванов и Новиков. Первый закупал в год до 200 тыс., второй - 50 тыс. четвертей пшеницы, которую перерабатывали на своих мельницах в муку высшего сорта - крупчатку, и отправляли до 200 тыс. четвертей ежегодно в Москву, Ростов и Царицын [30, с. 14].

Благодаря возможности дешевых перевозок к концу 1870-х гг. вся местность между Хопром и Медведицей стала важным районом товарного земледелия $[17$, с. V]. По отчетам
Общества Грязе-Царицынской дороги, отгрузка товаров со станций, находившихся в пределах Области войска Донского, выглядела следующим образом (табл. 1).

В Грязях местная продукция передавалась на смежные железные дороги для отправки дальше в центр страны. Значительная их часть уходила в Ригу, а оттуда морем в Европу.

В структуре вывоза безраздельно господствовали зерновые культуры. По станциям это распределялось так (табл. 2).

Прилегающие к дороге местности поставляли на станции такое количество грузов,

\section{Отгрузка основных товаров по направлениям}

Таблииа 1

Shipment of basic goods by directions

\begin{tabular}{|l|r|r|r|r|}
\hline \multirow{2}{*}{ Станция } & \multicolumn{2}{|c|}{ К Царицыну, пуд } & \multicolumn{2}{c|}{ К Грязям, пуд } \\
\cline { 2 - 5 } & 1878 г. & \multicolumn{1}{|c|}{1891 г. } & 1878 г. & \multicolumn{1}{c|}{1891 г. } \\
\hline Алексиково & 13172 & 18966 & 99833 & 88954 \\
\hline Урюпино & 125538 & 484383 & 1992675 & 2173035 \\
\hline Ярыженская & 31972 & 119568 & 698976 & 842075 \\
\hline Филоново & 54992 & 163982 & 361190 & 560361 \\
\hline Панфилово & 28372 & 193521 & 186571 & 386371 \\
\hline Кумылга & 47657 & 16707 & 186959 & 43130 \\
\hline Себряково & 184741 & 631877 & 816352 & 1033193 \\
\hline Раковка & 45942 & 1744 & 50085 & 55913 \\
\hline Арчеда & 30262 & 161244 & 83790 & 105986 \\
\hline Липки & 7168 & 1251 & 33644 & 2674 \\
\hline Лог & 6762 & 21673 & 30103 & 154307 \\
\hline Иловля & 35760 & 32086 & 11224 & 17055 \\
\hline Качалино & 15723 & 64943 & 115026 & 16911 \\
\hline Котлубань & - & 313 & - & 32 \\
\hline
\end{tabular}

Примечание. Составлено по: [18, с. 11;20, с. 14].

Таблица 2

Отгрузка основных товаров по станциям в 1878 г.

Shipment of basic goods by stations in 1878

\begin{tabular}{|l|r|r|r|r|r|r|r|r|}
\hline \multicolumn{1}{|c|}{ Станция } & $\begin{array}{c}\text { Пшеница, } \\
\text { пуд }\end{array}$ & \multicolumn{1}{c|}{$\begin{array}{c}\text { Рожь, } \\
\text { пуд }\end{array}$} & $\begin{array}{c}\text { Ячмень, } \\
\text { пуд }\end{array}$ & $\begin{array}{c}\text { Пшено, } \\
\text { пуд }\end{array}$ & $\begin{array}{c}\text { Мука } \\
\text { пшенич- } \\
\text { ная, пуд }\end{array}$ & $\begin{array}{c}\text { Мука } \\
\text { ржаная, } \\
\text { пуд }\end{array}$ & $\begin{array}{c}\text { Арбузы, } \\
\text { пуд }\end{array}$ & $\begin{array}{c}\text { Сало, } \\
\text { пуд }\end{array}$ \\
\hline Алексиково & 18358 & 44855 & 13951 & 1203 & 870 & 3000 & - & - \\
\hline Урюпино & 305478 & 309926 & 787373 & 51827 & 72140 & 220152 & 12335 & 3702 \\
\hline Ярыженская & 285315 & 180737 & 53260 & 1300 & - & 496 & - & - \\
\hline Филоново & 39740 & 181258 & 134473 & 37472 & 1373 & 4432 & 2100 & - \\
\hline Панфилово & 55818 & 40569 & 79828 & 1195 & - & 32 & - & - \\
\hline Кумылга & 37535 & 42275 & 107767 & 14666 & - & 1903 & - & - \\
\hline Себряково & 250558 & 237731 & 295118 & 29044 & 110463 & 29287 & 35 & 1697 \\
\hline Раковка & 4221 & 3918 & 13824 & 52595 & 1550 & 11069 & 2366 & 3381 \\
\hline Арчеда & 2402 & 41369 & 28500 & 6857 & 374 & 14206 & 4300 & 2131 \\
\hline Липки & 2614 & 5068 & 563 & 12756 & 10844 & 639 & 4032 & - \\
\hline Лог & 13773 & 13421 & 2520 & 1414 & 535 & 2318 & 583 & 14 \\
\hline Иловля & 1930 & 6510 & - & 1033 & 15812 & 1211 & - & - \\
\hline Качалино & 10751 & 33022 & 3572 & 338 & 691 & 3733 & - & 4579 \\
\hline
\end{tabular}

Примечание. Составлено по: [18, прил. 13]. 
перевезти которое быстро она была уже не в состоянии. Вокруг станций возникали настоящие залежи зерна, ждавшего своей очереди по две-три недели. Зерно хранилось в кучах под открытым небом и сильно портилось в случае выпадения осадков. В результате на станциях началось строительство зерновых складов.

Рост предложения сельскохозяйственного сырья стимулировал его переработку. В 1880-х гг. у станций железной дороги стали появляться крупные предприятия с машинным производством. В 1889 г. в Урюпинской станице была построена крупная мельница И. Зазулина производительностью 300 тыс. пудов пшеницы в год. Здесь имелся паровой двигатель на 160 л.с., трудилось 36 рабочих. К началу XX столетия в районе Грязе-Царицынской дороги работало уже несколько таких заведений, оснащенных самым современным оборудованием, например, мукомольная мельница Т.П. Клеева в хут. Моргуновском Михайловской станицы с паровым двигателем в 60 л.с., 12 рабочими и объемом производства 200 тыс. пудов. Крупнейшей мельницей Хоперского округа стала основанная в 1903 г. в хут. Самсоновском (бывший Привокзальный) на станции Филоново мельница и фабрика перловых и ячменных круп В.Л. Симбирцева и компании. Основной капитал общества достигал 220 тыс. руб., запасной - 156 тыс. рублей. Здесь имелось два дизельных двигателя на 390 л.с., было занято 60 рабочих. Мельница перерабатывала до миллиона пудов пшеницы в год [27, с. 691-692].

В Усть-Медведицком округе центром промышленности стала слобода Михайловка, расположенная рядом со станцией Себряково. В 1900 г. здесь работали две паровые мельницы со 123 работниками и годовым производством на 1401124 руб. [9, л. 194].

Земли станиц и волостей Второго Донского округа, расположенных в районе ГрязеЦарицынской дороги, не были столь плодородны. Паровые мельницы здесь появились только в начале $\mathrm{XX}$ в., опять-таки при станциях железных дорог - Логовского мукомольного товарищества на ст. Лог, Я.П. Фриккеля в Качалинской станице, две мельницы в хут. Калаче [3, с. 237]. В начале $\mathrm{XX}$ в. в засушливом Втором Донском округе доступный транспорт вызвал к жизни новую стремительно разви- вавшуюся отрасль хозяйства - бахчеводство. Выращивались в основном арбузы в районе железнодорожных станций Лог, Иловля и Карповка. С них отправлялось в год от 500 до 700 вагонов, в каждом из которых помещалось 610 пудов арбузов - то есть приблизительно от 915000 до 1282000 пудов [28, с. 103].

Поселения у станций железных дорог быстро росли, и к началу XX в. сравнялись или даже обогнали по численности населения соседние старые казачьи станицы. Так, хут. Фролов при ст. Арчеда насчитывал в 1873 г. 422 жителя [24, с. 105], а в 1897 г. - 3464 (в станице Кременской, к которой он относился, проживало 1603 чел.) [25, с. 214]. Хутор Привокзальный при ст. Филоново, возникший на пустом месте, насчитывал в 1897 г. 1563 жителя, что немногим уступало его станице Аннинской (2 373 чел.) [25, с. 272]. Но рекордсменом урбанизации оказался к 1897 г. хут. Калач (5 755 чел.), в четыре с лишним раза опередивший свою Пятиизбянскую станицу (1 129 жителей) [25, с. 162]. Население станицы Урюпинской после проведения железной дороги увеличилось более, чем в два раза - с 4512 чел. в 1873 г. [24, с. 147] до 11284 чел. в 1897 г. [25, с. 264]. В 1875 г. ввиду быстрого роста неказачьего населения в станице войсковой атаман предлагал военному министру отделить ярмарочное поселение от Урюпинской станицы и образовать отдельный город, но станичное общество выступило против, боясь потерять доходы от ярмарки $[14$, л. 1,9$]$.

С другой стороны, населенные пункты, которые оказались лишены столь удобного транспортного сообщения, развивались намного медленнее. Это станет очевидным, если сопоставить расположенную непосредственно у ст. Себряково слободу Михайловку и окружную станицу Усть-Медведицкую, удаленную от этой же станции на 98 верст. В 1873 г. в Усть-Медведицкой проживало 3456 чел. [24, с. 101], а в Михайловке-2 575 чел. [24, с. 141]. По переписи 1897 г. в окружной станице числилось 6190 [25, с. 200] жителей, а в Михайловке - уже 7506 [25, с. 242]. Усть-Медведицкая отстала от Михайловки и в промышленном отношении. Здешние предприятия: 1 свечной, 1 мыловаренный, 4 кирпичных, 1 пивоваренный и 1 кожевенный завод - работали лишь на местный рынок [2, с. 76]. 


\section{ОТ ВОЛЬНОГО КАЗАЧЕСТВА К СЛУЖИЛОМУ СОСЛОВИЮ}

Дешевое и круглогодичное железнодорожное сообщение привело к постепенному упадку ярмарочной торговли и росту розничной. Ярмарки оставались, но приобрели исключительно местный масштаб. Даже самая крупная Покровская ярмарка в ст. Урюпинской в несколько раз снизила свои обороты (за исключением торговли скотом) (табл. 3).

В 1900 г. во Втором Донском округе насчитывалось 413 торговых предприятий, в Усть-Медведицком - 301, в Хоперском - 501 (из них 170 в ст. Урюпинской) [4, с. 445-697].

Пострадавшим от Грязе-Царицынской дороги оказался только фурный промысел, некогда процветавший в крае. Уже в 1870-х гг. прекратился извоз в города Воронежской и Тамбовской губерний, а к началу XX в. окончательно заглохла перевалка грузов по направлению Дубовка - Качалинская. В справочнике МПС 1910 г. о движении по внутренним водным путям в перечне донских пристаней Качалинская отсутствует вовсе [6, с. 140]. Станица Качалинская почти перестала развиваться. До сооружения Грязе-Царицынской дороги ее население быстро росло с 2514 жителей в 1859 г. [22, с. 44] до 3120 чел. в 1873 г. [24, с. 85]. В последующие годы прирост резко замедлился, и в 1897 г. в станице проживало 3583 чел. [25, с. 150].

На рубеже XIX-XX вв. через территорию Второго Донского округа прошли еще две железные дороги. В 1897 г. акционерное общество Владикавказской железной дороги открыло движение по ветви от Царицына до
ст.Тихорецкой. Благодаря этому волжские грузы получили кратчайший выход на Северный Кавказ. В пределах Второго Донского округа были открыты станции Тундутово, Абганерово, Жутово, Котельниково. В 1900 г. новая Восточно-Донецкая линия акционерного общества Юго-Восточных железных дорог прошла от Царицына до ст. Лихой и соединила Волгу с Донецким каменноугольным районом. В результате появились станции Чир, Суровикино, Чернышков, Обливская.

Влияние этих линий на экономику округа следует оценивать как неоднозначное. На Грязе-Царицынской дороге станции, как правило, располагались рядом с крупными казачьими станицами и крестьянскими слободами, что стимулировало рост товарного производства в них. Эти же дороги прошли по малонаселенным местам, на значительном расстоянии от существующих крупных населенных пунктов. Прокладывая их, строители имели в виду прежде всего соображения экономии при строительстве, считая главной задачей этих дорог транзитную функцию.

Так, несмотря на усиленные просьбы местных жителей и войскового начальства, трасса Восточно-Донецкой железной дороги прошла в 12 верстах от крупнейшего в округе поселения - окружной станицы Нижне-Чирской, прежде являвшейся экономическим центром не только своего округа, но и прилегающих частей Донецкого и Усть-Медведицкого округов. Хотя строители провели к станице за свой счет шоссе от ближайшей станции Чир,

Обороты Урюпинской Покровской ярмарки

Trade turnovers of Uryupinsk Pokrovskaya fair

\begin{tabular}{|l|r|r|r|r|}
\hline \multicolumn{1}{|c|}{ Наименование товара } & $\begin{array}{c}\text { Привезено в } \\
1859 \text { г., руб. }\end{array}$ & $\begin{array}{c}\text { Куплено, } \\
\text { руб. }\end{array}$ & $\begin{array}{c}\text { Привезено в } \\
1899 \text { г., руб. }\end{array}$ & $\begin{array}{c}\text { Куплено, } \\
\text { руб. }\end{array}$ \\
\hline Мануфактура русская и иностранная & 5394450 & 2860800 & 1181540 & 732920 \\
\hline Бакалея, чай, сахар, табак & 379890 & 278690 & 192800 & 137373 \\
\hline Золотые, серебряные, церковная утварь & 46700 & 43300 & 48020 & 11520 \\
\hline Железный, скобяной & 580220 & 343100 & 99950 & 61350 \\
\hline Кожи и изделий из них & 560100 & 381000 & 132600 & 99354 \\
\hline Галантерея, москательные & 83630 & 61300 & 51000 & 28000 \\
\hline Сукно, холсты, шерсть, овчины & 152700 & 119300 & 29500 & 28000 \\
\hline Пушной товар & 26870 & 15800 & 128050 & 81650 \\
\hline Посуда фарфоровая и хрустальная & 21000 & 11300 & 27700 & 19800 \\
\hline Рыба & 35800 & 28950 & 21500 & 15000 \\
\hline Рогатый скот, лошади и овцы & 391250 & 236450 & 461288 & 450000 \\
\hline
\end{tabular}

Примечание. Составлено по: [23, л. 94]. 
это не помогло: торговля хлебом стала перемещаться на расположенные в более плодородных местностях станции Обливская и Морозовская при одноименных хуторах. По оценке обследовавшего Второй Донской округ в 1905 г. И. Тимощенкова, Нижне-Чирская была «убита в полном смысле по крайней мере на четыре пятых своих торгово-промышленных оборотов» [29, с. 113]. Об этом свидетельствует и замедление темпов роста населения станицы. За двадцать пять лет с 1873 по 1897 г. оно выросло с 4055 [24, с. 54] до 6786 жителей, то есть почти на $70 \%$ [25, с. 132]. За последующие же восемнадцать лет количество жителей станицы выросло всего на 16,7 \%: по данным 1915 г. в станице проживало 7919 чел. [1, с. 377]. Нижне-Чирская станица, так же как и Усть-Медведицкая, осталась чисто административным центром своего округа.

Используя наиболее выгодный рельеф местности, строители провели Восточно-Донецкую дорогу мимо Калача, отвернув от ст. Кривомузгинской. Станица Пятиизбянская, к которой принадлежал хутор, по словам И. Тимощенкова, оказалась в результате «<...> разорена совершенно. Здесь железные дороги все убили и ничего не дали. Убиты две переправы через Дон (одна в самой станице, другая при хуторе Калаче), убиты работы по нагрузке и разгрузке хлеба, которыми занято было до 3000 чел., убиты две лесные биржи, дававшие доходу 700 р., так как железная дорога образовала биржи на своей собственной земле, убита посаженная плата с иногородних, дававшая в станичный доход по 1500 p. в год. Последний станичный доход сократился до ничтожной суммы, потому что иногородцы массами уходят из торгового поселения Калач и продают свои усадьбы казачьему населению» [29, с. 115].

И.В. Тимощенков вообще считал влияние железных дорог одной из главных причин экономического упадка казачьего хозяйства Второго Донского округа в начале XX века. По его мнению, они «перевернули вверх дном всю жизнь местного населения», полностью уничтожив традиционный и очень важный для этих мест фурный промысел. В засушливой местности с очень неплодородными почвами «это было повсеместно в округе весьма выгодное занятие, бывшее во многих станицах и крестьянских во- лостях даже промыслом выгодным и сподручным, нежели земледелие и скотоводство». До проведения железных дорог, по данным И.В. Тимощенкова, «от Царицына до Ставрополя фурщики брали лес по 30 коп. с пуда, а там брали хлеб и везли в Ростов по 20 коп. Из Ростова в Царицын большей частью брали сахар по 15 коп. или покупали уголь, получая выгоду 7-10 коп. с пуда» [29, с. 114]. Теперь население лишилось привычного и надежного заработка.

Результаты. Подводя итоги, можно сделать вывод, что строительство в пореформенный период четырех железных дорог на севере и востоке Области войска Донского оказало значительное воздействие на экономическое развитие этих местностей. Однако влияние отдельных дорог отличалось. Первая из них по времени, Волжско-Донская, носила сугубо транзитный характер и привела к быстрому экономическому росту лишь одного поселения - хутора Калача, где осуществлялась перевалка грузов с железной дороги на речной транспорт. Гораздо заметней оказалась роль Грязе-Царицынской дороги, прошедшей по плотно заселенным и плодородным местам. Ее постройка привела к быстрому росту товарности сельского хозяйства, торговли и в конечном итоге появлению перерабатывающей промышленности индустриального типа. Поселения при станциях росли намного быстрее окрестных станиц и слобод, превращаясь в крупные экономические центры. Наибольшего успеха в развитии достигли станица Урюпинская и слобода Михайловка.

Самым противоречивым можно считать влияние на экономику востока Дона последних железных дорог, построенных на рубеже XIXXX вв. - Тихорецкой и Восточно-Донецкой. С одной стороны, они также усиливали спрос на продукцию местного производства (зерно и скот), привели к появлению новых центров торговли на их станциях. В то же время линии этих дорог были проложены без учета интересов местных жителей, новые станции располагались далеко от сложившихся поселений, что ставило их жителей в невыгодные условия. Особенно это касалось Восточно-Донецкой дороги, прошедшей мимо хут. Калача и ст-цы Нижне-Чирской. Строительство этих дорог привело к упадку извозного промысла, многие десятилетия являвшегося одним из самых доходных занятий жителей Второго Донского округа. 


\section{СПИСОК ЛИТЕРАТУРЫ}

1. Алфавитный список населенных мест Области войска Донского. - Новочеркасск : Областная войска Донского типография, 1915. - 658 с.

2. Балуев, П. С. Историческое и статистическое описание станиц и городов, посещаемых г. военным министром при объезде его высокопревосходительством Области войска Донского в 1900 г. / П. С. Балуев. - Новочеркасск : Обл. войска Донского тип., 1900. - 242 с.

3. Вся Донская область и Северный Кавказ. Книга администрации, торговли и промышленности на 1912 г. - Ростов н/Д : Электропечатня А.И. ТерАбрамян, 1912. -687 с.

4. Вся Область войска Донского на 1900 г. Книга администрации, торговли и промышленности. - Ростов н/Д : Типолитография А.И.Тер-Абрамян, 1900. $-723 \mathrm{c}$.

5. Герман, О. Б. Экономика казачьих и крестьянских хозяйств Дона во второй половине XIX начале XX века / О. Б. Герман // Казачество: прошлое и настоящее : сб. науч. тр. - Волгоград : Изд-во ВолГУ, 2000. - С. 164-184.

6. Количество судов и плотов и всех товаров, отправленных и прибывших по внутренним водным путям в 1910 г. // Статистический сборник Министерства путей сообщения. Вып. 120, ч. 1. - СПб. : Тип. М-ва путей сообщения, 1912. - 687 с.

7. Коломейцева, М. А. Социально-экономическое развитие крестьянских поселений на Дону во второй половине XIX - начале XX века : дис. ... канд. ист. наук / Коломейцева Мария Андреевна. Элиста, 2009. - 191 с.

8. Крестьянство Северного Кавказа и Дона в период капитализма / под ред. А. М. Анфимова. Ростов н/Д : Изд-во Рост. ун-та, 1990. - 256 с.

9. Материалы к отчету за 1900 г. // Государственный архив Ростовской области (ГАРО). Ф. 353.- Оп. 1.-Д. 514.

10. Никулин, П. Беляевская лесная пристань / П. Никулин // Донские областные ведомости. 1875. - 6 сент. (№ 69).

11. Никулин, П. Качалинская станица / П. Никулин // Донские областные ведомости. - 1875. 5 авг. (№ 60).

12. Номикосов, С. Ф. Статистическое описание Области войска Донского / С. Ф. Номикосов. Новочеркасск : Областное правление Войска Донского, 1884. - $762 \mathrm{c}$.

13. Об учреждении торгового поселения «Калач» на месте бывшего хутора Калачевского Пятиизбянской станицы // Полное собрание законов Российской империи. Собрание второе. Т. XXXVIII. Отделение первое. - СПб. : Тип. ІІ Отд-ния Собственной Е.И.В. Канцелярии, 1866. - 941 с.
14. О введении городового положения в Урюпинской станице // ГАРО. - Ф. 46. - Оп. 1. - Д. 1183а.

15. О статистических сведениях по ВолжскоДонской железной дороге // Российский государственный исторический архив. - Ф. 219. - Оп. 1.Ч. 4. - Д. 6614.

16. Отчет правления Волго-Донского общества по железной дороге за 1877 г. - СПб. : Тип. Бр. Шумахер, 1878. - Паг. разд.

17. Отчет правления общества Грязе-Царицынской железной дороги Борисоглебского земства за 1877 г. -СПб. : Тип. Ф.С. Сущинского. - Паг. разд.

18. Отчет правления общества Грязе-Царицынской железной дороги Борисоглебского земства за 1878 г. - СПб. : Тип. Ф.С.Сущинского. - Паг. разд.

19. Отчет правления Грязе-Царицынской железной дороги Борисоглебского земства за 1887 г. СПб. : Паровая скоропечатня Яблонской и Перрот, 1888. - Паг. разд.

20. Отчет по эксплуатации Грязе-Царицынской железной дороги за 1891 г. - СПб. : Типолитография С.Ф. Яздовского и К, 1892. - Паг. разд.

21. Ратушняк, В. Н. Сельскохозяйственное производство Северного Кавказа в конце XIX начале XX в. / В. Н. Ратушняк. - Ростов н/Д : Изд-во Рост. ун-та, 1989. - 251 с.

22. Списки населенных мест Российской империи. Вып. 12. Земля Донского войска. - СПб. : Изд. Центр. Стат. ком. МВД, 1864. - 102 с.

23. Списки поселений, в которых учреждены ярмарки // ГАРО. - Ф. 353. - ОП. 1. - Д. 506.

24. Список населенных мест Области войска Донского по переписи 1873 г. - Новочеркасск : Обл. войска Донского тип., 1875. - 275 с.

25. Список населенных мест Области войска Донского по первой всеобщей переписи населения 1897 г. - Новочеркасск : Обл. войска Донского тип., 1905. - Ч. 2. - 607 с.

26. Список фабрик и заводов европейской России. - СПб. : Тип. В. Киршбаума, 1903. - 840 с.

27. Список фабрик и заводов России 1910 г. : По официальным данным фабрич., подат. и горн. надзора. - М. ; СПб. ; Варшава : Л. и Э. Метуль и К, 1910. - $1034 \mathrm{c}$.

28. Тимощенков, И. В. Второй Донской округ Области войска Донского. Статистико-экономический очерк / И. В.Тимощенков // Сборник Областного Войска Донского статистического комитета. Вып. VI. - Новочеркасск : Частная донская типография, 1906. - С. 83-106.

29. Тимощенков, И. В. Станица Нижне-Чирская. Статистико-экономический очерк / И. В.Тимощенков // Сборник Областного Войска Донского статистического комитета. Вып. VI. - Новочеркасск: Частная донская типография, 1906. C. $107-130$. 
30. Тимощенков, И. В. Урюпинская станица и прилегающие к ней местности / И. В. Тимощенков. - Новочеркасск, 1875. - $71 \mathrm{c}$.

31. Хлыстов, А. П. Дон в эпоху капитализма. 60-е годы - середина 90-х годов XIX века. Очерки из истории Юга России / А. П. Хлыстов. - Ростов н/Д : Изд-во Рост. ун-та, 1962. - 332 с.

32. Karataev, V. B. To the issue of historical prerequisites and the significance of the construction of the railway network in the Caucasus (the late 19-th and early 20-th century era) / V. B. Karataev, I. B. Markaryan, R. M. Allalyev // Былые годы. 2015. - № 38 (4). - C. 933-939.

\section{REFERENCES}

1. Alfavitnyy spisok naselennykh mest Oblasti voyska Donskogo [Alphabetical List of Populated Localities of the Don Cossack Host Region]. Novocherkassk, Oblastnaya voyska Donskogo tipografiya, $1915.658 \mathrm{p}$.

2. Baluev P.S. Istoricheskoe i statisticheskoe opisanie stanits i gorodov, poseshchaemykh $g$. voennym ministrom pri obyezde ego vysokoprevoskhoditelstvom Oblasti voyska Donskogo v $1900 \mathrm{~g}$. [Historical and Statistical Description of the Stanitsas and Cities Visited by the Minister of War When Detouring the Don Cossack Host Oblast in 1900]. Novocherkassk, Oblastnaya voyska Donskogo tipografiya, 1900. 242 p.

3. Vsya Donskaya oblast i Severnyy Kavkaz. Kniga administratsii, torgovli i promyshlennosti na $1912 \mathrm{~g}$. [The Entire Don Region and North Caucasus. The Book of Administration, Commerce and Industry in 1912]. Rostov-on-Don, Elektropechatnya A.I. TerAbramyan, 1912. 687 p.

4. Vsya Donskaya oblast $i$ Severnyy Kavkaz. Kniga administratsii, torgovli $i$ promyshlennosti na $1912 \mathrm{~g}$. [The Whole Don Region in 1900. Book of Administration, Commerce and Industry]. Rostov-on-Don, Tipolitografiya A.I. Ter-Abramyan, 1900.723 p.

5. German O.B. Ekonomika kazachyikh i krestyanskikh khozyaystv Dona vo vtoroy polovine XIX - nachale XX veka [Economy of the Cossack and Peasant Farms of the Don in the Late $19^{\text {th }}-$ Early $20^{\text {th }}$ Century]. Kazachestvo: proshloe i nastoyashchee: Sbornik nauchnykh trudov [Cossacks. Past and Present. Collection of Scientific Papers]. Volgograd, Izd-vo VolGU, 2000, pp. 164-184.

6. Kolichestvo sudov i plotov i vsekh tovarov, otpravlennykh i pribyvshikh po vnutrennim vodnym putyam v $1910 \mathrm{~g}$. [Number of Vessels and Rafts and All Goods Sent and Arrived on Inland Waterways in 1910]. Statisticheskiy sbornik Ministerstva putey soobshcheniya [Statistical Collection of the Ministry of Railways]. Saint Petersburg, Tipografiya Ministerstva putey soobshcheniya, 1912, iss. 120, part 1.687 p.

7. Kolomeytseva M.A. Sotsialno-ekonomicheskoe razvitie krestyanskikh poseleniy na Donu vo vtoroy polovine XIX - nachale XX veka: dis. ... kand. ist. nauk [Socio-Economic Development of Peasant Settlements on the Don in the Late $19^{\text {th }}-$ Early $20^{\text {th }}$ Century. Cand. hist. sci. diss.]. Elista, 2009. 191 p.

8. Krestyanstvo Severnogo Kavkaza i Dona $v$ period kapitalizma [Peasantry of the North Caucasus and the Don in the Period of Capitalism]. Rostov-on-Don, Izd-vo Rostovskogo universiteta, $1990.256 \mathrm{p}$.

9. Materialy k otchetu za 1900 g. [Report Materials for 1900], Gosudarstvennyy arkhiv Rostovskoy oblasti (GARO) [State Archive of Rostov Region], F. 353, Op. 1, D. 514.

10. Nikulin P. Belyaevskaya lesnaya pristan [Belyaevskaya Wood Landing Stage]. Donskie oblastnye vedomosti, 1875, September 6, no. 69.

11. Nikulin P. Kachalinskaya Stanitsa. Donskie oblastnye vedomosti, 1875, August 5, no. 60.

12. Nomikosov S. Statisticheskoe opisanie Oblasti voyska Donskogo [Statistical Description of the Don Cossack Host Region]. Novocherkassk, Oblastnoe pravlenie Voyska Donskogo, 1884. 762 p.

13. Ob uchrezhdenii torgovogo poseleniya «Kalach» na meste byvshego khutora Kalachevskogo Pyatiizbyanskoy stanitsy [On Establishing "Kalach" Commercial Settlement on the Site of the Former Kalachevsky Khutor of Pyatiizbyanskaya Stanitsa]. Polnoe sobranie zakonov Rossiyskoy Imperii. Sobranie vtoroe [Complete Collection of Laws of the Russian Empire, $2^{\text {nd }}$ Collection]. Saint Petersburg, Tipografiya II Otdeleniya Sobstvennoy E.I.V. Kantselyarii, 1866, vol. 38, part 1.941 p.

14. O vvedenii gorodovogo polozheniya $\mathrm{v}$ Uryupinskoy stanitse [On Introducing the Municipal Statute in Uryupinskaya Stanitsa]. Gosudarstvennyy arkhiv Rostovskoy oblasti (GARO) [State Archive of Rostov Region], F. 46, Op. 1, D. 1183a.

15. O statisticheskikh svedeniyakh po VolzhskoDonskoy zheleznoy doroge [About Statistical Data on the Volga-Don Railway]. Rossiyskiy gosudarstvennyy istoricheskiy arkhiv [Russian State Historical Archive], F. 219, Op. 1, Part 4, D. 6614.

16. Otchet pravleniya Volgo-Donskogo obshchestva po zheleznoy doroge za $1877 \mathrm{~g}$. [Report of the Board of the Volga-Don Society on Railways for 1877]. Saint Petersburg, Tipografiya Bratyev Shumakher, 1878.

17. Otchet pravleniya obshchestva GryazeTsaritsynskoy zheleznoy dorogi Borisoglebskogo zemstva za $1877 \mathrm{~g}$. [Report of the Borisoglebsk Zemstvo Gryaze-Tsaritsyn Railway Association Board for 1877]. Saint Petersburg, Tipografiya F.S. Sushchinskogo. 
18. Otchet pravleniya obshchestva GryazeTsaritsynskoy zheleznoy dorogi Borisoglebskogo zemstva za $1878 \mathrm{~g}$. [Report of the Borisoglebsk Zemstvo Gryaze-Tsaritsyn Railway Association Board for 1878]. Saint Petersburg, Tipografiya F.S. Sushchinskogo.

19. Otchet pravleniya obshchestva GryazeTsaritsynskoy zheleznoy dorogi Borisoglebskogo zemstva za $1887 \mathrm{~g}$. [Report of the Borisoglebsk Zemstvo Gryaze-Tsaritsyn Railway Association Board for 1887]. Saint Petersburg, Parovaya skoropechatnya Yablonskoy i Perrot, 1888.

20. Otchet po ekspluatatsii Gryaze-Tsaritsynskoy zheleznoy dorogiza $1891 \mathrm{~g}$. [Report on the Operation of Gryaze-Tsaritsyn Railway for 1891]. Saint Petersburg, Tipolitografiya S.F. Yazdovskogo i K, 1892.

21. Ratushnyak V.N. Selskokhozyaystvennoe proizvodstvo Severnogo Kavkaza v kontse XIXnachale $X X v$. [Agricultural Production of the North Caucasus in the Late $19^{\text {th }}-$ Early $20^{\text {th }} \mathrm{c}$. $]$. Rostov-onDon, Izd-vo Rostovskogo universiteta, 1989. 251 p.

22. Spiski naselennykh mest Rossiyskoy imperii [Lists of Populated Places of the Russian Empire]. Zemlya Donskogo voyska [Land of the Don Cossack Host]. Saint Petersburg, Izdatelskiy Tsentr Statisticheskogo komiteta MVD, 1864, iss. 12. 102 p.

23. Spiski poseleniy, v kotorykh uchrezhdeny yarmarki [Lists of Settlements in Which Fairs are Established]. Gosudarstvennyy arkhiv Rostovskoy oblasti (GARO) [State Archive of Rostov Region], F. 353, Op. 1, D. 506.

24. Spisok naselennykh mest Oblasti voyska Donskogo po perepisi $1873 \mathrm{~g}$. [List of Populated Places of the Don Cossack Host Region According to the Census of 1873]. Novocherkassk, Oblasti voyska Donskogo tipografiya, 1875. $275 \mathrm{p}$.

25. Spisok naselennykh mest Oblasti voyska Donskogo po pervoy vseobshchey perepisi naseleniya $1897 \mathrm{~g}$. [List of Populated Places of the Don Cossack Host Region According to the First General Population
Census of 1897]. Novocherkassk, Oblasti voyska Donskogo tipografiya, 1905, part 2. 607 p.

26. Spisok fabriki zavodov evropeyskoy Rossii [List of Factories and Plants of European Russia]. Saint Petersburg, Tipografiya V. Kirshbauma, 1903. 840 p. 27. Spisok fabrik i zavodov Rossii 1910 g.: Po ofitsialnym dannym fabrich., podat. i gorn. nadzora [The List of Factories and Plants of Russia in 1910. According to the Official Data of the Factory and Mining Supervision]. Moscow, Saint Petersburg, Warsaw, L. i E. Metul i K Publ., 1910. 1034 p.

28. Timoshchenkov I.V. Vtoroy Donskoy okrug Oblasti voyska Donskogo. Statistiko-ekonomicheskiy ocherk [The Second Don District of the Don Cossack Host Region. Statistical and Economic Essay]. Sbornik Oblastnogo Voyska Donskogo statisticheskogo komiteta [Collection of the Statistics Committee of the Don Cossack Host Region]. Novocherkassk, Chastnaya donskaya tipografiya, 1906, iss. 4, pp. 83-106.

29. Timoshchenkov I.V. Stanitsa NizhneChirskaya. Statistiko-ekonomicheskiy ocherk [NizhneChirskaya Stanitsa. Statistical and Economic Essay]. Sbornik Oblastnogo Voyska Donskogo statisticheskogo komiteta [Collection of the Statistics Committee of the Don Cossack Host Region]. Novocherkassk, Chastnaya donskaya tipografiya, 1906, iss. 6, pp. 107-130.

30. Timoshchenkov I.V. Uryupinskaya stanitsa $i$ prilegayushchie kney mestnosti [Uryupinskaya Stanitsa and Surrounding Areas]. Novocherkassk, 1875. $71 \mathrm{p}$.

31. Khlystov A.P. Don v epokhu kapitalizma. 60-e gody - seredina 90kh godov XIX veka. Ocherki iz istorii Yuga Rossii [The Don in the Era of Capitalism. The $60 \mathrm{~s}-$ Mid 90s of the $19^{\text {th }}$ Century. Essays from the History of the South of Russia]. Rostov-on-Don, Izdvo Rostovskogo universiteta, 1962. 332 p.

32. Karataev V.B., Markaryan I.B., Allalyev R.M. To the Issue of Historical Prerequisites and the Significance of the Construction of the Railway Network in the Caucasus (the Late $19^{\text {th }}$ and Early $20^{\text {th }}$ Century Era). Bylye Gody, 2015, no. 38 (4), pp. 933-939.

\section{Information about the Author}

Andrei V. Lunochkin, Candidate of Sciences (History), Associate Professor, Department of Russian and General History, Archaeology, Volgograd State University, Prosp. Universitetsky, 100, 400062 Volgograd, Russian Federation, andrei.lunochkin@volsu.ru, https://orcid.org/0000-0002-7431-8906

\section{Информация об авторе}

Андрей Валентинович Луночкин, кандидат исторических наук, доцент кафедры отечественной и всеобщей истории, археологии, Волгоградский государственный университет, просп. Университетский, 100, 400062 г. Волгоград, Российская Федерация, andrei.lunochkin@volsu.ru, https://orcid.org/0000-0002-7431-8906 